\author{
REVIEW OF EUROPEAN AND COMPARATIVE LAW \\ VOLUME XLIII \\ YEAR 2020, ISSUE 4, pp. 103-118 \\ DOI: https://doi.org/10.31743/recl.10035
}

\title{
DIFFERENT FORMS OF VIOLENCE - SELECTED ISSUES
}

\author{
Krzysztof Mikotajczuk*
}

\begin{abstract}
Violence has been part of the human history since its very beginning. As some believe, it is "Cain's sin" that determines violent human behaviour. Though this belief is obviously simplified, it reflects the nature of man. We are eager to seek evil in others, in individuals and in social structures. It is not just the family that is oppressive. Violence is ubiquitous; it is inflicted by peer groups, social classes, organisations, and by the state. Violence is commonly defined as social behaviour against someone or something, the aggressor being on one side and the victim on the other. Usually, a narrow definition of violence is used; i.e., violence is understood as the use of force to obtain from others what they are not willing to give or what they do not want to do. However, violence is a more complex phenomenon. Some forms of violence are sophisticated and difficult to discern, not only in the behaviour of others but also in our own actions. Violence occurs on a micro-scale in the form of pressure, extortion, inducement, or restrictions, and on a macro-scale - as wars, crises, terroristic acts, or revolutions. Violence is not only physical and psychological; it may also be personal, structural, hidden, explicit, emotional, and rational. What follows, it takes place in a wide array of spaces: in culture, sport, politics, the media, in the public space and at home. Therefore, the narrow definition of violence fails to include many of its aspects, and as such it is
\end{abstract}

Rev. Dr. habil. Krzysztof Mikołajczuk, J.C.D., Associate Professor, Faculty of Law, Canon Law and Administration, The John Paul II Catholic University of Lublin; correspondence address: ul. Spokojna 1, 20-074 Lublin, Poland; e-mail: kmikolajczuk@kul.pl; https://orcid.org/0000-0001-9624-6934. 
not practical. Using such a definition, we are left with extreme cases, so in fact we define pathologies. A serious difficulty in defining violence is connected with defining human rights in a unified way. These vary from culture to culture and have been evolving throughout history. Violation of these rights constitutes the essence of what is referred to as violent behaviour. Each society defines and attempts to prevent violence differently, and also in its own way indicates those who judge the perpetrators of prohibited acts.

Keywords: Violence, definitions and forms of violence, social pathology, aggressor, victim

\section{INTRODUCTION}

Violence is an intentional act of using one's power and force against others. Violent behaviour infringes on the autonomy, individuality and dignity of another person or a group of people. Acts of violence usually occur between groups, communities, and nations. Violence may be a oneoff incident or may be repeated many times. It is the use of physical (or other) force against others to inflict suffering and harm on "the soul and body." Violence encompasses all non-accidental, or even purposeful acts that deviate from the social norms of interpersonal relationships. Violent acts can be divided into physical, psychological (mental), sexual, economic, and so-called negligent treatment. Violence can occur in various social contexts: in the family, at school, among peers, in the media, and in the virtual space. ${ }^{1}$

Violence is multi-faceted and multi-coloured. It is multidimensional. It may affect various categories of victims: children, women, men, but also the elderly, the disabled, foreigners, or animals. Unfortunately, it is often concealed in a "maze" of the family, environmental and social "collusion of silence." In the world of animals, violent behaviour is natural; otherwise, carnivores would not be able to survive. Hungry animals do not control their aggression, but when they are full, they are no longer aggressive, as in the animal world

1 Cf. Iwona Ulfik-Jaworska, "Przemoc," in Encyklopedia Katolicka Vol. 16, ed. Edward Gigilewicz (Lublin: Towarzystwo Naukowe KUL, 2012), 649-652. 
aggression is not an end in itself but rather a means of satisfying hunger and survival. Man, although superior to animals - not only due to his reason and the ability to control emotions, but also because he makes and observes norms that ban the use of violence - often resorts to violence and aggression against the weaker and those who are close to him. ${ }^{2}$

The article focuses on two types of violence: psychological (mental) and physical, which are examined especially in reference to children.

\section{VIOLENCE - AN ATTEMPT AT DEFINITION}

One might be tempted to say that 'evil' has always existed and it has always existed alongside 'good'. "According to Catholic Church teaching and Christian thought, evil arose when a creature with free will, and not as perfect as his Creator, went astray by rejecting God's love. This rejection of divine love, divine mercy and care has contributed to the eternal condemnation of man to suffering in which we must learn to exist. It seems, however, that it is only today, in the 21 st century that evil has triumphed with all its brutal openness and wildness, increasing human suffering and making it necessary to redefine humanity, which now encompasses much more elements that contrast with good. It is increasingly difficult for man to develop his personality properly, as he must constantly choose what is right, contrast good and evil, and set axiologically proper goals."3

The Catechism of the Catholic Church develops and complements the above considerations and states clearly that: "The first man was not only created good, but was also established in friendship with his Creator and in harmony with himself and with the creation around him.” ${ }^{\prime 4}$ Undoubt-

2 Elżbieta Krajewska-Kułak, Krystyna Kowalczuk, Agnieszka Kułak-Bejda, Andrzej Guzowski, and Wojciech Kułak, Różne barwy przemocy Vol. 1 (Białystok: Uniwersytet Medyczny, 2016), 6.

3 Ibidem, 13.

4 Katechizm Kościota Katolickiego (Poznań: Pallottinum, 1994), No. 374. "God is infinitely good and all His works are good. Yet no one can escape the experience of suffering or the evils in nature which seem to be linked to the limitations proper to creatures: and above all to the question of moral evil. Where does evil come from? "I sought whence 
edly, "evil pervades our lives, as does good, which constantly clashes with evil. It takes much work on self-improvement, much good will, or even sacrifice and heroism for good to prevail and triumph over evil [...]. Evil has never been easy to capture and define. It has always defied the human imagination." ${ }^{5}$

The issue of violence is still topical in literature and the media. With confidence, it can be stated that violence is unfortunately ubiquitous. It is inflicted in a variety of environments and spheres of life in modern civilizations. In today's world, it is increasingly visible and disturbing. So how can violence be defined? We pose this question at the beginning, and all the answers should be treated as a starting point for further considerations. Obviously, the concept of violence is not easy to define. ${ }^{6}$

It is commonly replaced with other concepts such as crime, brutality, or cruelty. Many authors define violence as "a specific relationship" between people that is based on the use of power, which seriously hinders the ability of a victim to self-defend. In this "clash", one person assumes the position of power over another; the victim is weaker and the perpetrator stronger. However, violence cannot be simply identified with aggression; what sets them apart is the position of power that one individual has over the other. In the case of violence, it is always the perpetrator that has this advantage, while in the case of aggression, power is frequently balanced. It seems that the main purpose of violent behaviour (the aggressor's aim) is to do harm, cause pain, inflict suffering, and to humiliate the victim. The perpetrator is aware of the effects of his actions, as violence is an intentional act aimed at controlling and subordinating the victim. Violence infringes on personal rights, such as the right to physical integrity, and human

evil comes and there was no solution» - says St. Augustine; and his own painful quest would only be resolved by his conversion to the living God. The «mystery of lawlessness» (2 Thess 2: 7) is clarified only in the light of the "mystery of our religion» (1 Timothy 3: 16). The revelation of divine love in Christ manifested at the same time the extent of evil and the superabundance of grace. We must therefore approach the question of the origin of evil by fixing the eyes of our faith on him who alone is its conqueror." Ibidem, No. 385.

5 Krajewska-Kułak et al., "Różne barwy przemocy", 19.

6 Cf. Joanna Różyńska, Przemoc wobec dzieci w rodzinie (Warszawa: Centrum Praw Kobiet, 2013), 13; also: Joanna Helios and Wioletta Jedlecka, Wspótczesne oblicza przemocy. Wybrane zagadnienia (Wrocław: Prawnicza i Ekonomiczna Biblioteka Cyfrowa, 2017), 15. 
dignity. Unfortunately, for many people today, violence has become an incomprehensible and shameful way of life. It has become almost permanent part of the family life where it is a common phenomenon and what is worse, it has become one of the many elements in the chain of aggression. ${ }^{7}$

Various forms of violence are described in the literature (as it was mentioned in the introduction). This is mainly psychological, physical, sexual, and economic violence, as well as negligent treatment.

\section{PSYCHOLOGICAL (EMOTIONAL) VIOLENCE}

According to the research compiled and published in 2010 by the Bureau for Analysis and Documentation at the Senate Chancellery, "psychological violence includes all the acts that aim at depriving the victim of self-confidence to make them feel lonely and dependent on the aggressor only. Different forms of psychological violence include, for example: coercing and threatening, humiliating, intimidating, demeaning, emotional blackmailing, insulting, blaming, convincing of mental illness, isolating, manipulating a sense of guilt, punishing by withholding feelings, denying sexual intercourse, ridiculing, embarrassing, controlling or preventing contact with others, prohibiting the use of a telephone or a car, imposing one's own views, prohibiting the victim to leave home, not showing interest, disrespecting, criticising constantly, accusing of inducing violence, demanding absolute obedience, depriving of sleep and food, or destroying items valuable to the victim. Psychological violence may result in low self-esteem, increased alertness, nervous tics, change of moods, and the inability to control one's emotions."

7 Ibidem, 15-16; also: Paweł Migała, Wybrane elementy patologii spotecznej w aspekcie ich uwarunkowań (Józefów: WSGE, 2011), 27.

8 Kancelaria Senatu. Biuro Analiz i Dokumentacji. Dział Analiz i Opracowań Tematycznych, Przeciwdziatanie przemocy $w$ rodzinie na tle rozwiązań legislacyjnych (Warszawa: Kancelaria Senatu. Biuro Analiz i Dokumentacji, 2010), 8. Psychological violence also includes: "repeated humiliation and ridicule, manipulation for one's own purposes, engaging in conflicts, lack of proper support; e.g., mocking somebody else's views, religion, background, imposing one's opinions, punishing by denying interest, feelings or respect, constant criticism, making a person believe that they suffer from mental illness, social 
Many authors believe that psychological violence is primarily an elusive form of mistreating the victim. Seemingly invisible, it is difficult to discern in everyday observation - which is usually based on what the aggressor says. ${ }^{9}$ It is only later that the effects of prolonged mental disintegration become noticeable. Undoubtedly, psychological violence is difficult to diagnose, "because what for an outsider may seem to be a trivial event or harmless behaviour may constitute a hard blow to the victim's psyche depending on their position in the family, in the group, or the frequency with which it occurs, and it may leave a permanent mark on their psyche, depriving them of their dignity and self-esteem." 10

In this regard, one cannot ignore the family and the most vulnerable family members; i.e., children. Violence manifests itself in the family through "verbal abuse, ridiculing, mocking, scaring, moralizing, forcing another person to be loyal, blackmailing, excessive control, arousing guilt, disrespecting dignity and privacy, destroying personal property and posses-

isolation; i.e., controlling and prohibiting or limiting contacts with other people, demanding obedience, depriving someone of sleep and food, using threats, verbal degradation (name-calling, humiliating, demeaning, embarrassing) [...] inflicting mental suffering by controlling and limiting the victim's contact with friends, school and workplace, forced isolation and imprisonment, forcing the victim to watch images and acts of violence, intimidating, threatening to cause physical harm both to someone close and to others, the use of threats, blackmailing, threatening to commit a suicide, continuous harassment, abusing pets and destroying private property." Joanna Helios and Wioletta Jedlecka, Wspótczesne oblicza przemocy. Wybrane zagadnienia, 19.

9 Ibidem, 19. Furthermore, Professor Irena Pospiszyl from The Maria Grzegorzewska University in Warsaw claims that psychological abuse "is often concealed under the mask of honesty and care, which seemingly cannot be found fault with.”. Irena Pospiszyl, Przemoc $w$ rodzinie (Warszawa: Wydawnictwa Szkolne i Pedagogiczne, 1994), 105. Violence against children is often referred to as "velvet-gloved violence. It may take the form of conscious cruelty to a child, and taking advantage of the child's helplessness in an intentional and perfidious way. But it may also consist in harming a child unknowingly due to being ignorant of the child's psyche and projecting one's own needs and model of happiness onto a child." Małgorzata Czerkawska and Mikołaj Markiewicz, "Przemoc wobec dzieci," accessed March 26, 2020, https://docplayer.pl/17654051-Przemoc-wobecdzieci-malgorza ta-czerkawska-mikolaj-markiewicz.html; also: Joanna Helios and Wioletta Jedlecka, Wspótczesne oblicza przemocy. Wybrane zagadnienia, 20.

10 Joanna Helios and Wioletta Jedlecka, Wspótczesne oblicza przemocy. Wybrane zagadnienia, 19. 
sions, throwing away souvenirs, letters, or temporarily isolating a child." 11 Czerkawska and Markiewicz believe that "threatening children with kicking them out of the house, putting them in foster care, or abandoning them, and saying that you do not love them anymore, or that they make you ill, constitute an extremely perfidious psychological torture, especially when such threats are made to the youngest children who unquestionably believe in what their parents say, and are unaware of how real parental punishments and threats may be. Children treated in this way lose their sense of security, they experience anxiety, constant stress, sadness and loneliness. It is impossible to predict how deep and extensive wounds such violent behaviour inflicts on their psyche. Another manifestation of emotional violence is emotional coldness, i.e. not showing affection to a child. Parental love is necessary for a child to develop properly and then to function in their adult life. Children that are deprived of love cannot build healthy emotional relationships with others. When they grow up, they may be unable to show affection to their family members. Emotional violence is also used by overprotective parents. Excessive control and protecting a child against all possible failures may also affect the child's behaviour." ${ }^{12}$

It is difficult to diagnose the consequences of violence, especially when dealing with psychological (emotional) violence. Emotional abuse does not leave bodily injuries; however, it causes fear, anxiety, a sense of injustice and of not being loved by parents, rebellion, desire for revenge and other persistent experiences. It is described as a state of "painful mental suffering" and "moral anguish." Emotional abuse cannot be demonstrated in simple steps, as this would require examining certain family conditions. The recognizable consequences of emotional violence include: persistent headaches and dizziness, stomach and muscle aches, diarrhoea, body shivering, excessive sweating, urinary and faecal incontinence, vomiting, and chest pain. ${ }^{13}$

11 Małgorzata Czerkawska and Mikołaj Markiewicz, "Przemoc wobec dzieci," 9.

12 Małgorzata Czerkawska and Mikołaj Markiewicz, "Przemoc wobec dzieci," 9; also: Paweł Migała, Wybrane elementy patologii spotecznej w aspekcie ich uwarunkowań, 27.

13 Cf. Czerkawska and Markiewicz, "Przemoc wobec dzieci," 10. Similarly, Helios and Jedlecka conclude that: "psychological violence leaves traces in the child's psyche. The consequences of psychological violence are comparable to the consequences of physical violence, or even more serious, and at the same time they are not easy to spot. This makes 
It is worth noting that emotional violence has long-lasting effects on the psychophysical development of abused children. Children who are "emotionally abused do not accept themselves and have low self-esteem. Parents keep complaining about them, which further lowers their confidence. They start to have problems at school and are unable to meet school requirements, as they cannot count on their parents' help and often do not get on well with peers. Not being successful in the family and at school makes such children reluctant to take effort, because they believe they are bound to fail. As everything goes wrong, why make an effort to try. In this way, they lose a sense of purpose, which often results in suicide attempts. The consequences of emotional abuse also include the following cognitive, emotional and behavioural disorders: difficulty in controlling emotions, attention deficit disorder, distrust, phobias, sleep disorders, running away from home, and alcohol and drug addiction." ${ }^{14}$

Furthermore, it turns out that emotional violence has its fatal consequences "in the adult life of victims. Adults who were emotionally abused as children often hold negative expectations towards others and distrust them, they also tend to escape from the "dark past" into drug addiction, alcoholism and even crime. According to researchers, the remote somatic consequences of emotional violence include: increased blood pressure, cardiac arrhythmia,

it difficult to provide the child with proper support. Long-term psychological violence in particular, can disturb the child's development in many areas: social, emotional, and cognitive. Children who experience emotional abuse often grow up feeling guilty, and they have low self-esteem. The consequences of emotional abuse are especially severe if it is committed by mothers. The research clearly shows that exposure to mental violence in childhood has long-term effects. For example, it has been demonstrated that the effects of emotional abuse may vary depending on the form of abuse. Children who were repeatedly terrorized by their caretakers tend to suffer from anxiety and somatic disorders in their adult lives; whereas those who were ignored and emotionally neglected may develop borderline personality disorder. As a result of experiencing constant anxiety and fear, abused children develop a variety of psychosomatic disorders; e.g., sleep disorders, pain, vomiting, diarrhoea, eating disorders, as well as general illness and bad mood. In addition, they often suffer from enuresis (involuntary urination) and encopresis (involuntary soiling). Moreover, they are destructive and aggressive, have problems with focusing attention or are withdrawn, indifferent, nervous and depressed." Joanna Helios and Wioletta Jedlecka, Przemoc wobec dzieci w rodzinie (Wrocław: Prawnicza i Ekonomiczna Biblioteka Cyfrowa, 2019), 83-84.

14 Małgorzata Czerkawska and Mikołaj Markiewicz, "Przemoc wobec dzieci," 10. 
muscular hypertonia, gastric disorders, and psychosomatic diseases. Victims of emotional violence display low self-esteem also in adult life, which is hardly surprising considering how they were treated by their parents. They feel guilty and mentally dependent on their parents. People experiencing emotional abuse have a disturbed sense of identity, display strong need to control others, and they alienate themselves from others. They often fall into depression, are anxious and withdrawn, and feel lonely. They always try to do everything right, are self-aware, and strive for perfection. Children who experienced emotional violence often resort to it later in their lives. This is called the vicious circle mechanism and it may be the most drastic effect of violence, not only emotional, but also other forms of violence." ${ }^{15}$

Recently, the concept of gaslighting, which refers to an authoritative technique of manipulation, has become widely used in the context of psychological violence. In many abusive relationships, one person tends to manipulate their partner in such a way that the victim has the impression of becoming insane, is emotionally unstable, and no longer trusts himself, but only his perpetrator. This is one of the most cruel and sophisticated forms of violence. Gas-lighters are typically males with psychopathic traits. They attempt to dominate their partners gradually and incapacitate them to gain full emotional control over them. Gas-lighters are individuals who abuse various psychotropic substances and frequently come into conflict with the law. In their "sick" thinking, they do not want to leave their partners, yet they are unable to respect them. As individuals with psychopathic traits, they do not respect anyone, but need others (often those close to them) only to satisfy their own needs. The victims of gas-lighters are typically people with low self-esteem (wives, partners, children). They often experienced violence themselves when growing up (as children and adolescents), which renders them unaware of the "insanity" of their situation. Frequently, even being alert does not help when the aggressor uses manipulation. Sometimes a clever manipulator can destroy another person so skilfully and slowly that the victim is unaware of being entangled in a sick relationship, and their self-confidence is gradually weakened. ${ }^{16}$

15 Małgorzata Czerkawska and Mikołaj Markiewicz, "Przemoc wobec dzieci," 10.

16 Cf. Joanna Helios and Wioletta Jedlecka, Wspótczesne oblicza przemocy. Wybrane zagadnienia, 20. The term gaslighting is derived from the title of a pre-war stage play "Gas 


\section{PHYSICAL VIOLENCE}

Another form of violence is physical violence. The term refers to violating the physical integrity of another person; it is an intentional act causing body injury, inflicting pain, or a real threat of causing body injury. The consequences of physical violence may include: fractures, bruises, burns, cut wounds, etc. The aggressor inflicts these "wounds" by kicking, choking, pushing, slapping in the face, using firearms and sharp instruments. Physical violence often takes place in the home and in the family. Research carried out in Poland and worldwide clearly indicates that parents (although not just them) use a variety of corporal punishment measures, sometimes - quite peculiar. "Physical punishment ranges from light spanking to heavy beatings with visible signs such as bruises, wounds, burn marks, swelling, etc. It is expressed in the form of open aggression aimed at a child, parent or other person." ${ }^{17}$

Light" by British playwright Patrick Hamilton (1904-1962) and the film adaptations of the play. It tells a story of an overbearing husband abusing his wife by attempting to persuade her that she is insane. As a result of her husband's manipulations, the woman becomes increasingly paranoid, frightened and uncertain. Ibidem, 20. The concept of gaslighting is mentioned here as it clearly shows the inhumanity of family violence. For more details, see the English-language literature: Paige Sweet, "The Sociology of Gaslighting," American Sociological Review, Vol. 84 no. 5 (2019): 851-875; Andrew Spear, "Gaslighting, Confabulation, and Epistemic Innocence," Topoi 39, no. 1 (2020): 229-241; Robin Stern, The Gaslight Effect. How to Spot and Survive the Hidden Manipulation Others Use to Control Your Life (New York: Morgan Road Book, 2018); Natascha Rietdijk, "(You Drive Me) Crazy. How Gaslighting Undermines Autonomy” (MA thesis submitted for the Research Master's Philosophy Utrecht University, June 22, 2018; student number: 5591686, Utrecht University Library, 2018).

17 Joanna Helios and Wioletta Jedlecka, Wspótczesne oblicza przemocy. Wybrane zagadnienia, 18. When presenting their own views and those of other authors, Helios and Jedlecka add the following claim: "It is obvious that the use of physical punishment against children has been present in many cultures and societies, including Poland and other countries of the Eastern and Central Europe. Numerous institutions and organisations are taking measures to limit the use of physical punishment. This practice is also the subject of social research which aims to diagnose how common the use of physical punishment is and what is the attitude towards such parental practices. It is pointed out that there is no single and commonly accepted definition of physical punishment, because it is difficult to delineate and describe this phenomenon. S. Wójcik quotes Strauss's definition, 
Helios and Jedlecka firmly conclude that "in practice it is difficult to draw a line between physical punishment used as a correction tool and violence used by a parent, because the motives for parental behaviour are not always clear and what is more, parents are rarely aware of those motives. Therefore, it seems to be more appropriate to view physical punishment as some dimension of physical violence, rather than as a completely separate phenomenon. This view is accepted by most experts dealing with violence. The most important argument in favour of this view is that the use of physical punishment against children meets the definition of violence - it is an intentional act that causes harm to a child. This harm can be described as the actual damage to health, but also as the risk of such damage. Undoubtedly, the use of physical punishment also violates children's rights." ${ }^{18}$

The World Health Organisation defines physical violence as an act that results in the child experiencing physical harm. It may be a permanent, occasional or a one-off act. "The definition of physical violence against children as it was formulated by the United Nations points out to the intentional use of physical force that results in or has a high likelihood of resulting in harm to the health, life, development and dignity of the child [...] Spanking is considered to be an acceptable form of disciplining a child. A clear line is drawn between beating and a spank, with the former being condemned and the latter being approved of. There is a tendency to think that spanking and physical violence belong to two different categories. Yet, spanking has the same harmful consequences as other forms of physical violence." ${ }^{19}$

which states that «it is an intentional use of physical force against a child to cause pain, but not injury to the body, and which is used for the purposes of correction and control of child's behaviour». Therefore, in this definition, the emphasis is placed on the purpose of punishment, and at the same time on the fact that physical punishment is by definition associated with inflicting pain ... ." Joanna Helios and Wioletta Jedlecka, Przemoc fizyczna wobec dzieci. Perspektywa prawna (Warszawa: Wydawnictwo C.H. Beck, 2019), 4; also: Szymon Wójcik, "Postawy wobec kar fizycznych i ich stosowanie w sześciu krajach Europy Środkowo-Wschodniej. Wyniki międzynarodowego badania The Problem of Child Abuse," Dziecko Krzywdzone, no. 4 (2013): 7-8.

18 Joanna Helios and Wioletta Jedlecka, Przemoc fizyczna wobec dzieci. Perspektywa prawna, 4.

19 Joanna Helios and Wioletta Jedlecka, Przemoc fizyczna wobec dzieci. Perspektywa prawna, 7; also: Joanna Szafran, "Kary fizyczne jako przejaw przemocy wobec dzie- 
When an attempt is made to define physical violence, attention should be paid to the following aspects: "violence is an intentional act, which means it is purposeful. This does not mean that the perpetrator's aim must be to hurt the child, violence is often treated as a means to an end. This end may be educational as well. Violence refers to beating not only to inflict pain, but also for the "child's good", to make a child learn more, be obedient, or to prevent a child from hurting themselves, etc. This means that even if the motive for beating is good, it is still violent behaviour. We speak about physical violence not only when a child suffers the actual harm, but also when there is a high risk that some act will result in such harm. The definitions of violence emphasise that it concerns in particular the relationship of a child with parents, caretakers or those exercising power[...]. It should be remembered, however, that violence can take so many different forms that the catalogue of violent acts is not exhaustive." ${ }^{20}$

ci," Dziecko Krzywdzone, no. 4 (2017): 56. With some concern, it should be noted that: "The results of the research conducted among adult Poles show that every other person (47.1\%) personally knows the family where violence against children is used. The form of violence that children are exposed to depends on their sex. Boys are more likely to experience physical violence, while girls are more exposed to psychological violence. Most frequently, violence against children is inflicted by parents, more frequently by fathers than by mothers. Fathers are more likely to inflict violence on boys, while mothers on girls." Helios and Jedlecka, Przemoc fizyczna wobec dzieci. Perspektywa prawna, 9; also: Migała, Wybrane elementy patologii spotecznej $w$ aspekcie ich uwarunkowań, 31. Extensive, though drastic information on violence against children can also be found in: Jacek Błeszczyński and Anita Rodkiewicz-Rożek, "Przemoc wobec dziecka w rodzinie," Wychowanie w Rodzinie, no. 5 (2012): 145-162. Migała describes it as follows: "the most common forms of aggression towards children include: spanking (used by $84.4 \%$ of parents surveyed), hitting with a hand (used by $61.8 \%$ of parents surveyed, with respondents saying that they do it rarely, 21\% - quite often, and 5\% - very often), $43.5 \%$ of respondents used hard spanking, $40.6 \%$ admitted to spanking a child with a belt or some other objects, about a dozen percent admitted to acts of considerable brutality (hitting blindly, beating with fists, kicking, and incapacitating)." Migała, Wybrane elementy patologii spotecznej $w$ aspekcie ich uwarunkowań, 34.

20 Szymon Wójcik, "Przemoc fizyczna wobec dzieci," Dziecko Krzywdzone, no. 11 (2012): 8; also: Joanna Helios and Wioletta Jedlecka, Przemoc wobec dzieci w rodzinie, 17; also: Joanna Helios and Wioletta Jedlecka, Przemoc fizyczna wobec dzieci. Perspektywa prawna, 7-8. An honest and clear description of physical abuse against children is offered by Joanna Różyńska, who claims that: "Beating and physical punishment are unacceptable discipline measures. Nothing can justify raising a hand on a child. Children must not be 
Statistics on violence against children are collected and examined by the courts, the Polish Ombudsman, the police, as well as by the Domestic Violence Cross-functional Teams ${ }^{21}$ and numerous assistance and crisis intervention centres. Data on violence against children collected in the so-called "Blue Card" procedure is one of the main sources of statistical information on this problem. The Blue Card procedure was implemented in Poland in 1998, and ever since it has been the most reliable integrated system of assisting and monitoring families where cases of violence have been reported. ${ }^{22}$ It is worth noting here that this procedure is used mainly when reporting and analysing physical violence. Unfortunately, physical violence is very often accompanied by psychological and sexual abuse. Incidents of violence against children that are particularly dramatic, are recorded by the police as offences under Art. 207 of the Polish Penal Code. ${ }^{23}$

Article 207 of the Polish Penal Code provides: " $\$ 1$. Anyone who mentally or physically mistreats a person close to him or her, or another person in a permanent or temporary state of dependence to the offender is liable to imprisonment for between three months and five years. $\$ 1$ a. Anyone who mentally or physically mistreats a minor or a person who is vulnerable because of his or her mental or physical condition is liable to imprisonment for between six months and eight years. $\$ 2$. If the act specified in $\$ 1$ or $1 \mathrm{a}$ is carried out with particular cruelty, the offender is liable to imprisonment for between one and ten years. $\$ 3$. If the act specified in $\$ \$ 1$

beaten because they are weaker, aggression breeds aggression, beating does not affect the conscience, but it is only hard on the skin - therefore, it is ineffective, beating humiliates, deliberate beating is inhumane and beating in anger is dangerous, because an adult does not control the force of the impact; beating is banned by the Constitution of the Republic of Poland, the Family and Guardianship Code and the Convention on the Rights of the Child." Joanna Różyńska, Przemoc wobec dzieci w rodzinie, 8.

${ }_{21}$ More in: Ustawa z dnia 29 lipca 2005 r. o przeciwdziałaniu przemocy w rodzinie (Dz. U. z 2005 r., Nr 180, poz. 1493); interesting information can be found in the extensive ministerial report: Ministry of Labour and Social Policy, Krzywdzenie dzieci w Polsce. Raport (Warszawa: Ministerstwo Pracy i Polityki Społecznej, 2008).

22 More in: Rozporządzenie Rady Ministrów z dnia 13 września 2011 r. w sprawie procedury „Niebieskiej Karty” oraz wzorów formularzy „Niebieska Karta” (Dz. U. z 2011 r., Nr 209, poz. 1245).

23 Cf. Joanna Helios and Wioletta Jedlecka, Przemoc wobec dzieci w rodzinie, 18-19. Ustawa z dnia 6 czerwca 1997 r. - Kodeks karny (Dz. U. z 1997 r., Nr 88, poz. 553 ze zm.). 
or 2 results in a suicide attempt by the afflicted party, the offender is liable to imprisonment for between 2 and 12 years."

In terms of proper family functioning, one of the fundamental aims of criminal law is to eliminate family violence. Although there is still much to be done in this area, the legislator has essentially linked family protection with Art. 207 of the Penal Code, which defines the offence of mistreatment. ${ }^{24}$ As S. Hypś notes, following the Supreme Court interpretation, the offence of mistreatment violates "basic principles of family life, affects family cohesion and durability, it is an important factor influencing the dissolution of marriage and family breakdown, and consequently - weakens the child-rearing function of the family, which in turn has harmful consequences for the physical, mental and moral development of children and young people and their social adaptation" (Polish Supreme Court, Resolution of 9 June 1976, VI KZP 13/75, OSNKW 1976, No. 7-8, item 86; Polish Supreme Court, Resolution of 25 November 1971, VI KZP 40/71, OSNKW 1972, No. 2, item 27). Furthermore, "there is no doubt that mistreatment undermines family integrity, hindering or even preventing its development, which takes place through raising children and ensuring proper care for parents" (Polish Supreme Court, Judgement of 2 February 1974, I KRN 33/74, OSNKW 1975, No. 3-4, item 38), thus "the welfare of the whole family is the subject of protection in this case (Polish Supreme Court, Judgement of 5 February 1996, Prok. and Pr. 1996, No. 10, item 1). ${ }^{25}$ Likewise, the family and proper family functioning are recognised as an important good and protected under Art. 207 of the Polish Penal Code. ${ }^{26}$

\section{CONCLUSIONS}

In conclusion, it should be emphasised that the features of a criminal act under Art. 207 of the Polish Penal Code are described by the verb 'to

24 Cf. Sławomir Hypś, "Rozdział XXVI. Przestępstwo przeciwko rodzinie i opiece," in Kodeks karny. Komentarz, ed. Alicja Grześkowiak, Krzysztof Wiak (Warszawa; Wydawnictwo C.H. Beck, 2015), 1036.

25 Sławomir Hypś, "Rozdział XXVI. Przestępstwo przeciwko rodzinie i opiece," $1036-1037$.

26 Sławomir Hypś, “Rozdział XXVI. Przestępstwo przeciwko rodzinie i opiece,” 1037. 
mistreat' and two alternate adverbs 'physically' or 'mentally', which specify the perpetrator's behaviour that makes them subject to criminal liability. Physical and mental mistreatment, as already mentioned, may occur separately or together. However, to be criminally liable, it is enough for the perpetrator to commit one form of violence. Therefore, it seems that the statutory distinction between physical and mental abuse is fully justified. Life experience clearly shows that all physical suffering involves mental suffering, but not all mental suffering is linked to physical pain. Mental mistreatment involves inflicting "injuries" that have a harmful effect on the mental sphere and well-being. "The judiciary determines the intensity and extent of psychological suffering based on the facts of the case and circumstances. Physical abuse involves inflicting physical pain that has a negative effect on the human body. However, inflicting pain by the perpetrator does not have to involve physical injury or violation of bodily integrity. Sometimes treating a victim in a way that aims to damage their health condition can also be classified as physical abuse." ${ }^{\prime 2}$ A serious difficulty in defining violence is connected with defining human rights in a unified way. These vary from culture to culture and have been evolving throughout history. Violation of these rights constitutes the essence of what is referred to as violent behaviour. Each society defines and prevents violence differently and in its own way indicates those who judge the perpetrators of prohibited acts.

\section{REFERENCES}

Błeszczyński, Jacek, and Anita Rodkiewicz-Rożek. "Przemoc wobec dziecka w rodzinie.” Wychowanie w Rodzinie, no. 5 (2012): 145-162.

Czerkawska, Małgorzata, and Mikołaj Markiewicz. "Przemoc wobec dzieci." Accessed March 26, 2020. https://docplayer.pl/17654051-Przemoc-wobec-dzieci-malgorzata-czerkawska-mikolaj-markiewicz.html.

Helios, Joanna, and Wioletta Jedlecka. Przemoc fizyczna wobec dzieci. Perspektywa prawna. Warsaw: Wydawnictwo C.H. Beck, 2019.

Helios, Joanna, and Wioletta Jedlecka. Przemoc wobec dzieci w rodzinie. Wrocław: Prawnicza i Ekonomiczna Biblioteka Cyfrowa, 2019.

27 Sławomir Hypś, "Rozdział XXVI. Przestępstwo przeciwko rodzinie i opiece," 1039. 
Helios, Joanna, and Wioletta Jedlecka. Wspótczesne oblicza przemocy. Wybrane zagadnienia. Wrocław: Prawnicza i Ekonomiczna Biblioteka Cyfrowa, 2017. Hypś, Sławomir. "Rozdział XXVI. Przestępstwo przeciwko rodzinie i opiece.” In Kodeks karny. Komentarz, edited by Alicja Grześkowiak, and Krzysztof Wiak, 1027-1071. Warsaw: Wydawnictwo C.H. Beck, 2015.

Kancelaria Senatu. Biuro Analiz i Dokumentacji. Dział Analiz i Opracowań Tematycznych, Przeciwdziatanie przemocy $w$ rodzinie na tle rozwiazań legislacyjnych. Warsaw: Kancelaria Senatu. Biuro Analiz i Dokumentacji, 2010.

Katechizm Kościota Katolickiego. Poznań: Pallottinum, 1994.

Krajewska-Kułak, Elżbieta, Krystyna Kowalczuk, Agnieszka Kułak-Bejda, Andrzej Guzowski, and Wojciech Kułak. Różne barwy przemocy, Vol. 1. Białystok: Uniwersytet Medyczny, 2016.

Migała, Paweł. Wybrane elementy patologii spotecznej w aspekcie ich uwarunkowań. Józefów: WSGE, 2011.

Ministerstwo Pracy i Polityki Społecznej. Krzywdzenie dzieci w Polsce. Raport. Warsaw: Ministerstwo Pracy i Polityki Społecznej, 2008.

Pospiszyl, Irena. Przemoc w rodzinie. Warsaw: Wydawnictwa Szkolne i Pedagogiczne, 1994.

Rietdijk, Natascha. "(You Drive Me) Crazy. How Gaslighting Undermines Autonomy." MA thesis submitted for the Research Master's Philosophy Utrecht University, June 22, 2018; student number: 5591686, Utrecht University Library 2018.

Różyńska, Joanna. Przemoc wobec dzieci w rodzinie. Warsaw: Centrum Praw Kobiet, 2013.

Spear, Andrew. "Gaslighting, Confabulation, and Epistemic Innocence." Topoi 39, no. 1 (2020): 229-241.

Stern, Robin. The Gaslight Effect. How to Spot and Survive the Hidden Manipulation Others Use to Control Your Life. New York: Morgan Road Book, 2018.

Sweet, Paige. "The Sociology of Gaslighting." American Sociological Review Vol. 84, no. 5 (2019): 851-875.

Szafran, Joanna. "Kary fizyczne jako przejaw przemocy wobec dzieci." Dziecko Krzywdzone, no. 4 (2017): 55-80.

Ulfik-Jaworska, Iwona. "Przemoc." In Encyklopedia Katolicka, Vol. 16, edited by Edward Gigilewicz, 649-652. Lublin: Towarzystwo Naukowe KUL, 2012.

Wójcik, Szymon. "Postawy wobec kar fizycznych i ich stosowanie w sześciu krajach Europy Środkowo-Wschodniej. Wyniki międzynarodowego badania The Problem of Child Abuse." Dziecko Krzywdzone, no. 4 (2013): 7-25.

Wójcik, Szymon. "Przemoc fizyczna wobec dzieci." Dziecko Krzywdzone, no. 11 (2012): 7-28. 